\title{
INFLATION AND MONETARY POLICY IN RUSSIA IN JANUARY 2016
}

\author{
A.Bozhechkova
}

The Consumer Price Index (CPI) in January 2016 advanced 1.0\% (3.9\% in January 2015) and the January median one-year ahead expected inflation rate increased 0.3 percentage points to $16.7 \%$, reaching the highest value since February 2015 when the median one-year ahead expected inflation rate was driven up to 18.1\% by the ruble's devaluation in late 2014/early 2015. Overall, the Russian ruble's real effective exchange rate is now relatively fundamentally substantiated owing to a free-floating exchange rate regime in the Russian foreign exchange market which faces neither interventions by the Bank of Russia nor panic sentiments of economic agents. We do not anticipate the ruble to depreciate considerably unless new shocks kick in.

The Consumer Price Index (CPI) in January 2016 gained 1.0\% (0.8\% in December 2015), up 9.8\% from the same period of 2014 and down 3.1 percentage points from December 2015 (Fig. 1). The core inflation ${ }^{1}$ in January stood at $100.8 \%$, an increase of 0.2 percentage points compared to the previous period.

Food prices in January 2016 saw the same growth rate $101.2 \%$ as in December 2015. In terms of price growth, fruit and vegetable produce were ranked first (up 6.2\% in January 2016, up 6.6\% in December 2015). Granulated sugar prices increased considerably (up $2.4 \%$ in January 2016, down $0.9 \%$ in December 2015). Egg prices slowed down (up 2.1\% in January 2016, up 6.4\% in December 2015).

Non-food prices increased $0.7 \%$ in January (0.4\% in December 2015). The following products saw their price accelerate slightly: tobaccos (up from 1.2\% in December 2015 to $1.7 \%$ in January 2016), household audio-visual equipment (up from 1.0\% in December 2015 to 1.1\% January 2016), electric and other household appliances (0.8\% in December 2015, 1.0\% January 2016), building materials (0.2\% in December $2015,0.5 \%$ in January 2016), medicaments (up from 0.2\% in December 2015 to 0.5\% January 2016), this being evidence of another effect of exchange rate pass-through on the price of this family of goods as a result of the ruble's depreciation in late 2015/early 2016.

Prices and tariffs of paid services to individuals in January increased $1.0 \%$, whereas in December they were up $0.7 \%$. The price of the following services increased: utility services (up 0.4\%), passenger transport services (up 1.3\%), sanatorium and health-improving services (up 1.5\%), medical services (up 1.9\%), as well as outbound travel (tourism) services (up 5.1\%) (Fig. 2).

The median one-year ahead expected inflation rate in January was up 0.3 percentage points to $16.7 \%$, according to LLC INFOM's public opinion polls, which are published monthly by the Bank of Russia. This is the highest value since February 2015, when the median one-year ahead expected inflation

1 The baseline consumer price index is an indicator which reflects the level of inflation in the consumer market, excluding seasonal factors (fruit and vegetable produce prices) and administrative factors (tariffs of regulated types of service, etc.). The index is also calculated by Russia's Federal State Statistic Service (Rosstat). 
rate stood at $18.1 \%$ as a result of the ruble's depreciation in late 2014/ early 2015. In our view, the 2016 year-end inflation rate will most likely reach $10 \%$ amid the sweeping devaluation of the Russian ruble in December 2015/January 2016.

The $\mathrm{CPI}$ gained $0.6 \%$ in the first 20 days of February. Monetary factors were a headwind for inflation build-up. Slow growth in bank lending volumes continued to be responsible most for relatively slow growth rates in the monetary base.

The monetary base (broad definition) shrank in January 2016, down to $\mathrm{Rb} 10,507.1 \mathrm{bn}$ earlier in February. The amount of cash in circulation, including cash in vaults of credit institutions, declined $6.5 \%$ to $\mathrm{Rb} 7,971.6 \mathrm{bn}$, and banks' deposits in the Bank of Russia were down $27.2 \%$ to $\mathrm{Rb} 406.2 \mathrm{bn}$. Banks' balances on correspondent accounts held with the Bank of Russia increased $9.6 \%$ to $\mathrm{Rb} 1,747.0 \mathrm{bn}$, and commercial banks' required reserves increased $3.4 \%$ to $\mathrm{Rb} 382.3 \mathrm{bn}$. The narrow monetary base (cash plus the required reserves) in January contracted by $6.3 \%$ to $\mathrm{Rb} 8,197.7 \mathrm{bn}$ (Fig. 3).

In January commercial banks saw their average daily reserves increase $3.6 \%$ to $\mathrm{Rb} 1749.4 \mathrm{bn}$ as compared to December 2015, and the averaged reserves in the period between 10 January and 10 February 2016 were worth $\mathrm{Rb} 1,367.1$ bn (up $3.7 \%$ over the earlier period). In the period between 10 December 2015 and 10 January 2016, commercial banks' surplus reserves ${ }^{1}$ averaged $\mathrm{Rb}$ 481.4bn (down 28\% over the earlier period), of which banks' deposits on the accounts held with the Russian central bank averaged

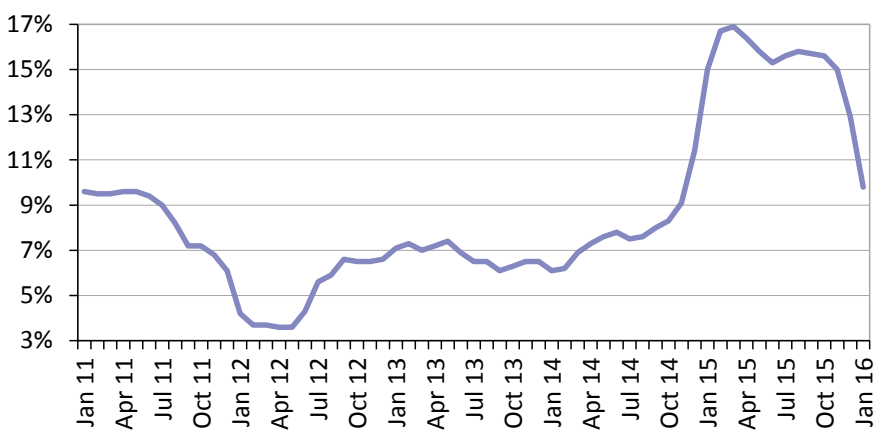

Source: Russia's Federal State Statistic Service (Rosstat). Fig. 1. CPI growth rate in 2011-2015 (YOY percentage change)

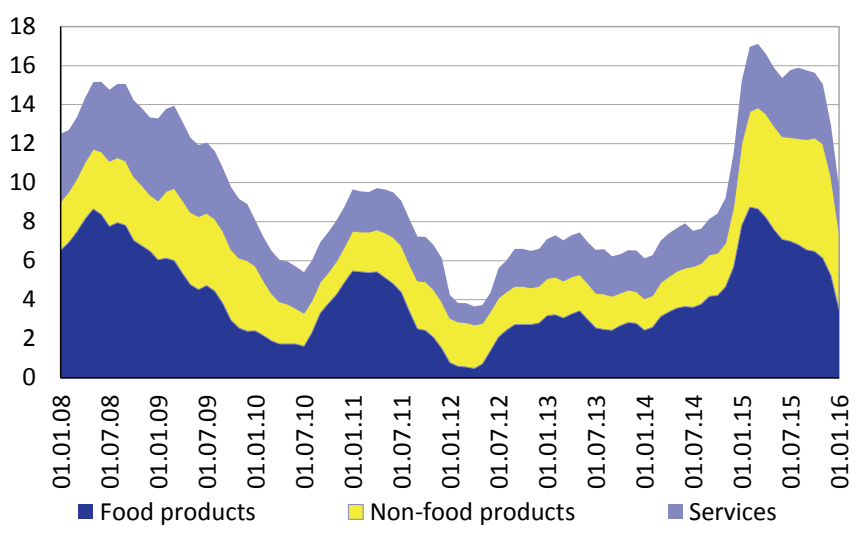

Source: Rosstat.

Fig. 2. The year-over-year contribution of the key components to the CPI in 2008-2015

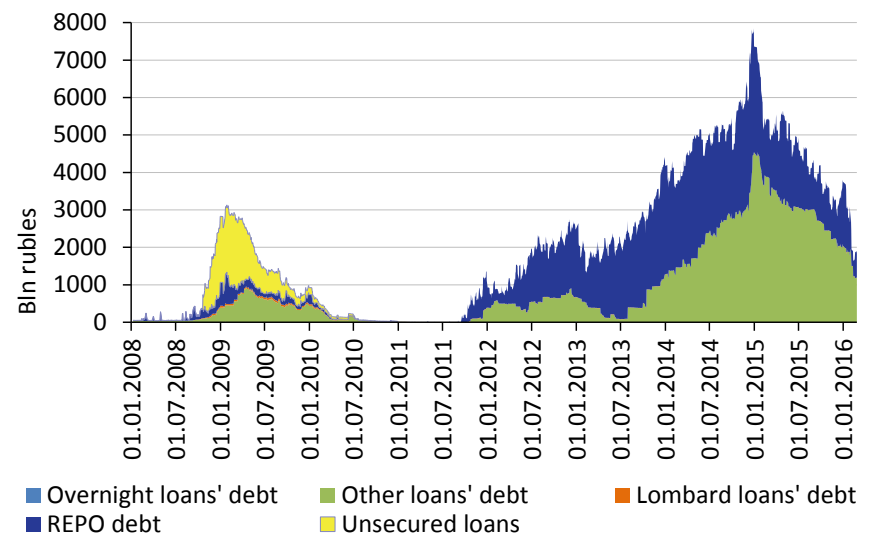

Source: Russia's central bank.

Fig. 3. The dynamics of the monetary base (narrow definition) and Central Bank holdings of foreign currency and gold (international reserves) in 2007-2016

1 Commercial banks' surplus reserves held with Russia's central bank refer to the amount of commercial banks' deposits held with the Bank of Russia and correspondent accounts less the averaged amount of required reserves. 
$\mathrm{Rb} 333.4 \mathrm{bn}$, up 1.9\% over the earlier period, and correspondent accounts, less the averaged reserves, in the period under review stood at an average of $\mathrm{Rb} 148.1 \mathrm{bn}$ (down $57 \%$ over the earlier period).

As of 1 February 2016, loans, deposits and other funds that credit institutions raised from the Bank of Russia reached $\mathrm{Rb} 4.6$ trillion, down $14.4 \%$ December to date. Banks' debt on repos dropped by $48.9 \%$ to $\mathrm{Rb} 0.9$ trillion, and debts on loans secured by non-marketable assets decreased by $8.9 \%$ to $\mathrm{Rb} 1.8$ trillion (Fig. 4). Banks' debt on repos in February shrank by $38.2 \%$ to $\mathrm{Rb} 0.6$ trillion as debts on other loans contracted by $38.9 \%$ to $\mathrm{Rb} 1.2$ trillion, this being evidence of considerably lower demand for the central bank's money by credit institutions.

In January 2016, the MIACR (Moscow InterBank Actual Credit Rate) on overnight interbank rubledenominated loans didn't cap the upper bound of the interest rate band, staying at an average of $10.9 \%$ (11.1\% in November 2015). In February the interbank lending rate averaged around $10.5 \%$ (Fig. 5).

Banks' debts owed to Russia's central bank in currency repos dropped $2.9 \%$ to $\$ 24.2 \mathrm{bn}$, of which $\$ 18.9 \mathrm{bn}$ in one-year repos and $\$ 5.2 \mathrm{bn}$ in 28 -day repos. As a reminder, the central bank announced on 27 November 2015 it will resume

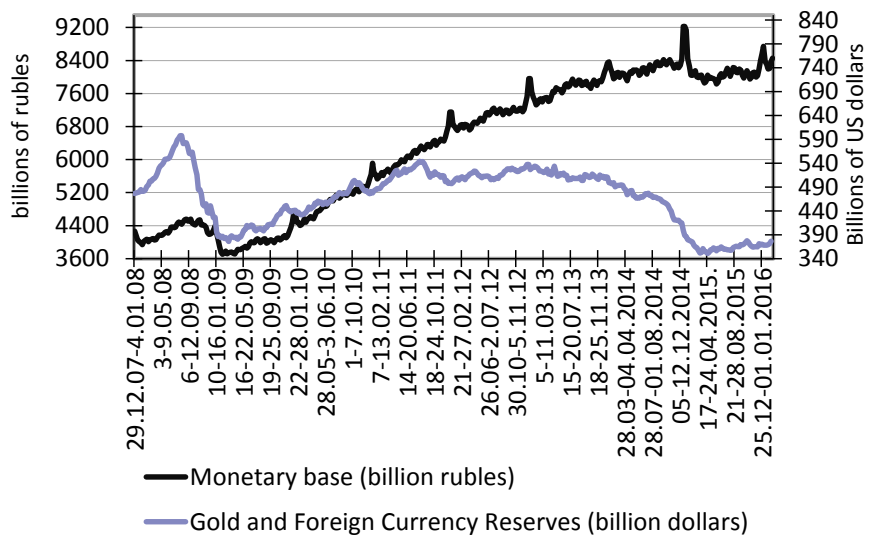

Source: Russia's central bank.

Fig. 4. Commercial banks' ruble-denominated debt (the key instruments) to the Bank of Russia in 2008-2016

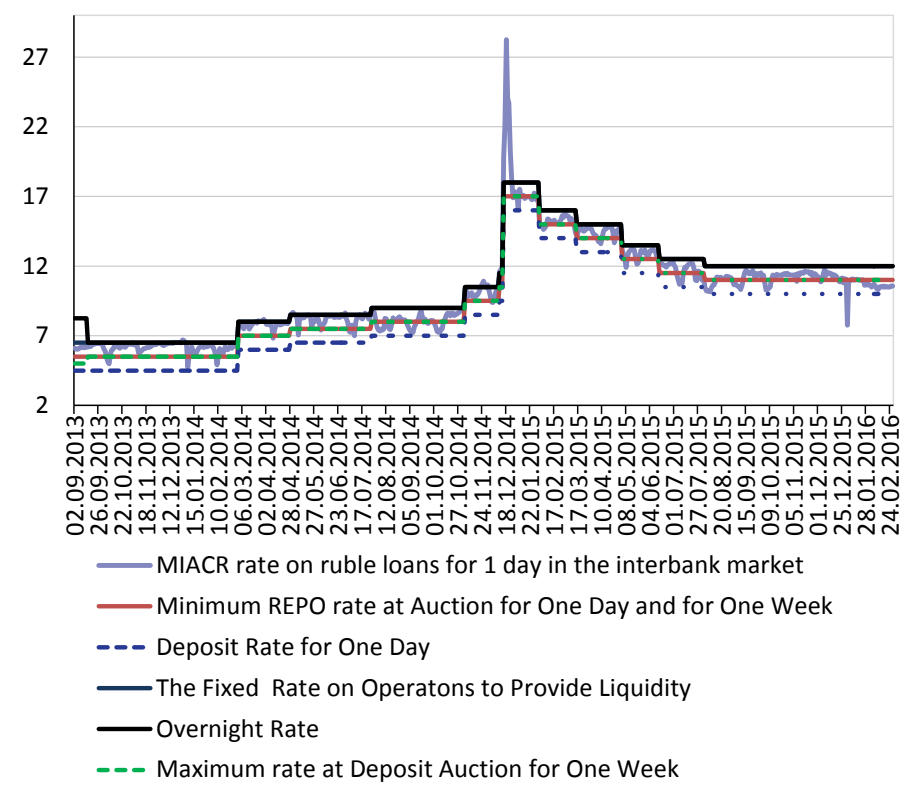

Source: Russia's central bank.

Fig. 5. The Bank of Russia interest rate band and the dynamics of the interbank lending market in 2012-2016 (\% per annum) from 14 December 12-month currency repo auctions. At the same time, the Bank of Russia lifted the interest rate by LIBOR plus 3 p.p. for this type of auctions (previously, LIBOR plus 2.5 p.p.). Three attempts at holding a currency repo auction in January failed because of high costs of funding. The 28-day currency repo auction was much more attractive for commercial banks. For instance, $\$ 5.2 \mathrm{bn}$ at $2.5 \%$ per annum were allotted in January as part of a 28-day currency repo auction. With such interest rate policy, Russia's central bank will facilitate restructuring banks' foreign-currency debt to the central bank towards 1-month repo auctions. Note that the data for 26 February show that banks' debt to the central bank in currency repos shrank further by $15.1 \%$ to $\$ 20.5$ bn because bank's debt in 1-year currency repos contracted to $\$ 10.3 \mathrm{bn}$, whereas the debt in 28-day currency repos increased to $\$ 10.2 \mathrm{bn}$. 
Thus, banks had lower demand for foreign-currency refinancing despite the further devaluation of the Russian ruble, considerable foreign-denominated debt payments to be met in December 2015 (\$21.9bn of principal repayments, $\$ 2$ bn of interest payments as per foreign debt repayment schedule) and a U.S. Federal rate hike. Credit institutions appear to have sufficient holdings of foreign currency, which they accumulated last year.

The Bank of Russia did not carry out interventions in the foreign exchange market in the period between August 2015 and January 2016. At the same time, the central bank's international reserves swelled in January from $\$ 368.4 \mathrm{bn}$ to $\$ 371.6 b n$ as of 1 February 2015. Note that the international reserves increased mostly because resident banks repaid their liquidity drawings in foreign currency, and due to gold monetization, amid a negative effect of exchange rate and market revaluation.

The Russian ruble depreciated in real terms in January 2016. The ruble's real effective exchange rate

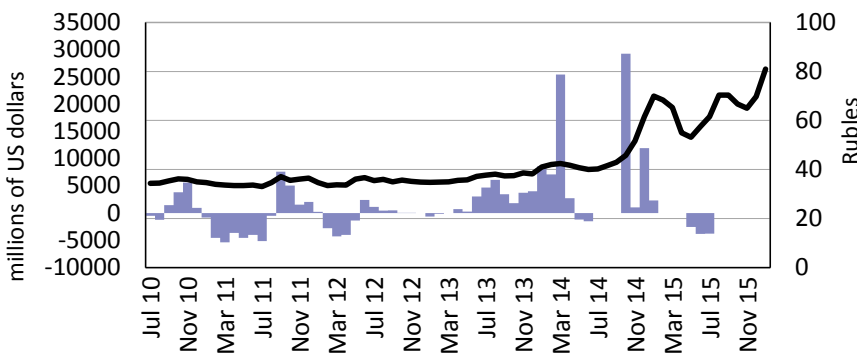

Currency interventions ("+" - net purchase, "-" - net sales)

-Official currecy basket / Rub (end of period)

Source: Russia's central bank.

Fig. 6. Bank of Russia's foreign currency intervention and the ruble exchange rate against the currency basket in March 2010-2015

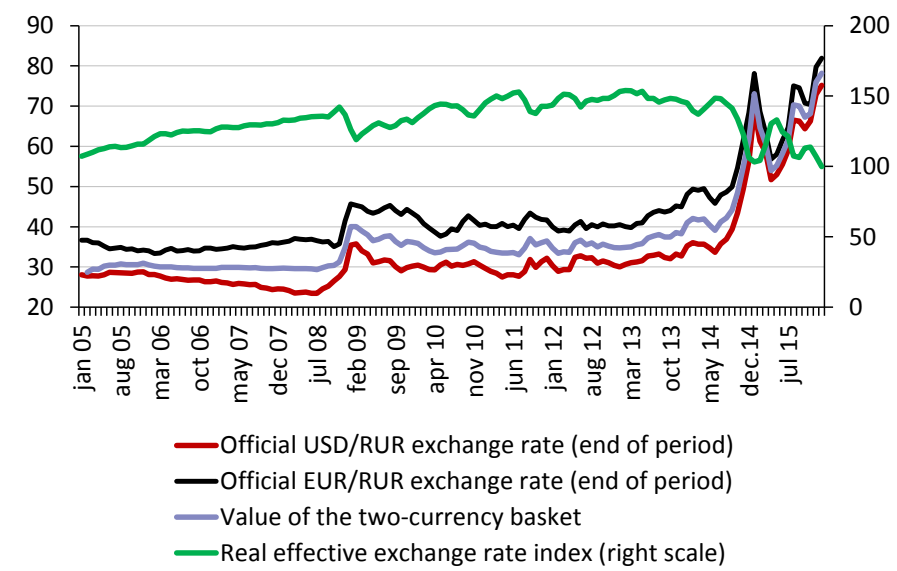

Source: Russia's central bank.

Fig. 7. Ruble exchange rate indicators in January 2005-2015 lost $6.7 \%$ (down $5.9 \%$ in December 2015), being equal to the level seen in September 2003 (Fig. 7). Overall, note that the Russian ruble's real effective exchange rate has is now relatively fundamentally substantiated owing to a free-floating exchange rate regime in the Russian foreign exchange market which faces neither interventions by the Bank of Russia nor panic sentiments of economic agents. We do not anticipate the ruble to depreciate considerably unless new shocks kick in.

The Russian ruble lost 4.7\% against the US dollar in December 2015, from 72.9 to 76.3 rubles per dollar as the euro gained $4.0 \%$ against the ruble, up to 82.8 rubles per euro, and the value of the dual-currency basket increased $4.3 \%$ to 79.2 rubles. On 22 January 2016, the official dollar-ruble exchange rate hit an all-time high of 83.6 rubles per dollar. The ruble's weakening in January was determined mostly by the worsening conditions in the oil market. The ongoing fall of oil prices in February 2016 dragged the ruble down by $0.1 \%$ against the US dollar to 76.4 rubles per dollar. 